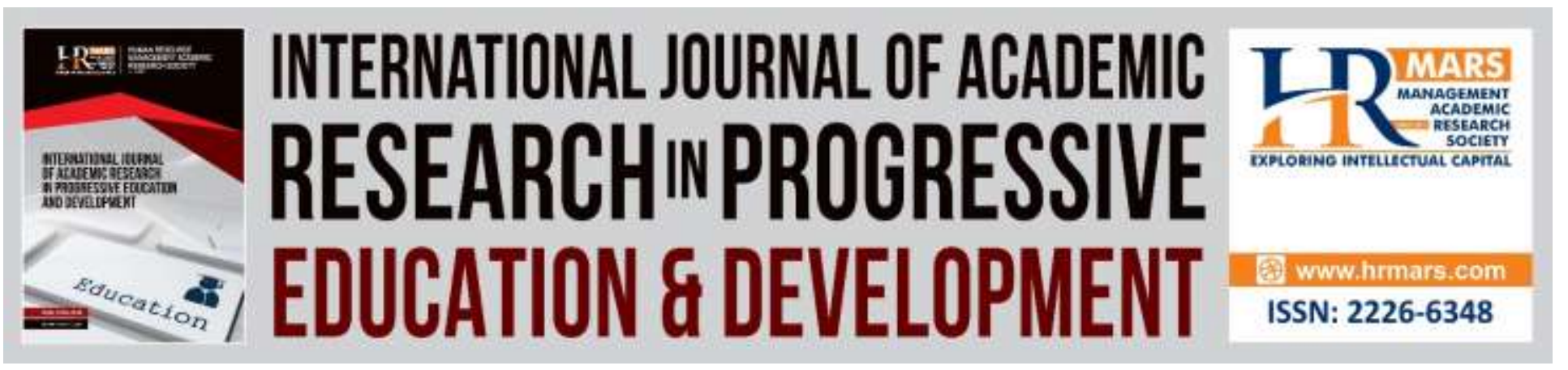

\title{
Relationship Matrix Comparing University Geography Courses and Secondary School Standard Curriculum in Malaysia
}

Mohmadisa Hashim, Hanifah Mahat, Nasir Nayan, Yazid Saleh \& Koh Liew See

To Link this Article: http://dx.doi.org/10.6007/IJARPED/v8-i2/5641

DOI: $10.6007 /$ IJARPED/v8-i2/5641

Received: 19 Feb 2019, Revised: 25 March 2019, Accepted: 11 April 2019

Published Online: 16 April 2019

In-Text Citation: (Hashim, Mahat, Nayan, Saleh, \& See, 2019)

To Cite this Article: Hashim, M., Mahat, H., Nayan, N., Saleh, Y., \& See, K. L. (2019). Relationship Matrix Comparing University Geography Courses and Secondary School Standard Curriculum in Malaysia. International Journal of Academic Research in Progressive Education and Development, 8(2), 54-68.

Copyright: (C) 2019 The Author(s)

Published by Human Resource Management Academic Research Society (www.hrmars.com)

This article is published under the Creative Commons Attribution (CC BY 4.0) license. Anyone may reproduce, distribute, translate and create derivative works of this article (for both commercial and non-commercial purposes), subject to full attribution to the original publication and authors. The full terms of this license may be seen

at: http://creativecommons.org/licences/by/4.0/legalcode

Vol. 8(2) 2019, Pg. 54 - 68

http://hrmars.com/index.php/pages/detail/IJARPED

JOURNAL HOMEPAGE

Full Terms \& Conditions of access and use can be found at http://hrmars.com/index.php/pages/detail/publication-ethics 


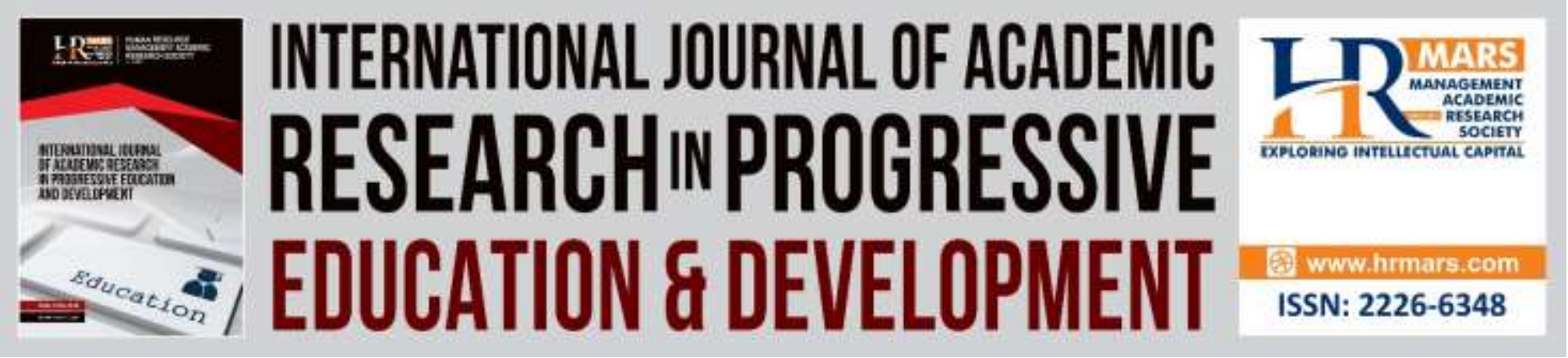

\title{
Relationship Matrix Comparing University Geography Courses and Secondary School Standard Curriculum in Malaysia
}

\author{
Mohmadisa Hashim, Hanifah Mahat, Nasir Nayan, Yazid Saleh \& \\ Koh Liew See \\ Department of Geography and Environment, Faculty of Human Sciences, Sultan Idris Education \\ University, 35900 Tanjong Malim, Perak, Malaysia
}

\begin{abstract}
The purpose of this article is to draw a comparison between the Bachelor of Education (B.Ed.) Geography curriculum and the Standard Document for Curriculum and Assessment (SDCA) of secondary school geography. The study includes analysis of the geography curriculum document at Sultan Idris Education University (UPSI) and the Standards-Based Curriculum for Secondary School (SBCSS) for the subject of geography. A relationship matrix of parallel themes was identified using ATLAS.ti software. The themes examined were physical geography, human geography, and geographic skills. The results of the analysis show that 14 out of 16 courses in the B.Ed. in Geography were comparable to the SDCA of Geography SBCSS for Forms 1 to 3. There were eight subjects in the SDCA of Geography SBCSS that were not related to the instructional plan of the B.Ed. in Geography: two Form 1 topics - Position and Sketch Map of Malaysia; three Form 2 topics - Telecommunications in Malaysia, Types of and Transportation Development in Asia, and Green Technology; and three Form 3 topics - Natural Plants in Malaysia, Wildlife in Malaysia, and Recycling. The study concludes that the Department of Geography \& Environment needs to improve the existing courses and add relevant courses to the B.Ed. Geography in order for it to be compatible with the latest school curriculum. The findings of this study should enhance the education system at university level by helping to produce future teachers who possess the latest knowledge and $21^{\text {st }}$ century skills in line with Malaysia's aspirations of becoming a developed nation.
\end{abstract}

Keywords: B. Ed Geography, Standards-Based Curriculum for Secondary School, ATLAS.ti, Sultan Idris Education University, Geography curriculum 


\section{Introduction}

Education plays a very important role in developing and promoting a nation because education is the main factor which improves the competitiveness of the nation. As stated by Kaya (2018), it has been widely accepted that education plays the most important role in national development and community wellbeing. Therefore, the education system and its curriculum will be reformed from time to as a result of the country's need to achieve a developed and competitive nation on the world stage. According to Nor Fauzian and Fauziah Hanim (2015), the formation and reform of education systems are due to the wishes and needs of students and countries, and global needs. This change has also caused the subject curriculum taught in schools to undergo reforms, including the subject of geography. Along with the changes to the curriculum, reviews of the courses offered at university level also have to be carried out. This is to ensure that the courses offered are in line with the latest curriculum requirements, especially in public universities that offer education programmes - such as Sultan Idris Education University (UPSI), Malaysia - which should coordinate with the latest school curriculum. UPSI is a national educational institution that produces professionals in the field of teaching and trains quality teachers to produce excellent students in an effort to develop the national education system (Mohd Mustamam et al., 2010).

An essay by Merfat Ayesh (2016) emphasises that educators are the main characters in the curriculum implementation process because educators are the most knowledgeable about teaching practices and are responsible for introducing the curriculum in the classroom. As the current school geography curriculum changes, the existing courses offered in the Bachelor of Education (B.Ed.) in Geography programme at the Department of Geography and Environment, Faculty of Human Sciences (FHS), UPSI, need to be reviewed to ensure that they are relevant and fit with the curriculum currently adopted at the school level. This is because the B.Ed. in Geography programme is offered to future teachers who will teach geography at schools. Hence, these geography teachers have to master the latest contents in line with the focus of the Standard Document for Curriculum and Assessment (SDCA) of Geography. Hence, this study aims to examine the UPSI B.Ed. in Geography curriculum and the SDCA of geography in schools, especially for Forms 1,2 , and 3 , using a comparison matrix.

\section{Literature Review}

\section{The Concepts of Curriculum and Geography}

'Curriculum' is a Latin word which consists of two meanings: i) run, race, or course; and ii) racecourse or career (Connelly \& Lantz, 1991; Egan, 2003; Djuwairiah, 2014). According to Nor Fauzian and Fauziah Hanim (2015), a curriculum is a written document designed for learning and contains a list of learning topics to be carried out by educators. In the Malaysian context, curriculum refers to all educational plans to achieve the national education goals as outlined in the National Education Philosophy and supervised by an educational institution - i.e., the Ministry of Education (MOE) Malaysia (Jamil \& Norlia, 2008). However, a curriculum is dynamic in nature (Soon Singh, 2013) and it will change according to current developments. Therefore, reviews should be conducted at least once every five years so that the education system in Malaysia is always updated. To implement the curriculum in schools, teachers play an important role in ensuring that students master the knowledge. 
In general, geography is a discipline related to the environment that describes all forms of living and non-living things that exist around humans. The word 'geography' is derived from the Greek word 'geo' which means 'the earth' and 'graphien' which means 'to write' or, in other words, 'to explain/describe/portray about earth' (Mohamad Suhaily Yusri, 2002). This discipline is divided into two major sub-disciplines: namely, physical geography and human geography. In the context of curriculum, the focus of geography education is to understand the relationship between environmental issues and the community, as well as their impact on the daily lives of the community. Therefore, geography education is important in getting students to understand how to acquire knowledge and prepare themselves to analyse and understand complex and relevant world issues in various relationships (Esteves, 2012).

\section{Secondary School Curriculum in Malaysia}

In line with the history of changes in the geography syllabus in secondary schools, the Teaching and Learning process (T-L) of the subject of geography is based on the 1956 syllabus, which was standardised for all types of schools in the early years after independence (Voon, 1990). Beginning in 1968, the geography T-L was converted to the syllabus for secondary school (Malay Medium) IImu Alam or Natural Science - where it only stated the topics that needed to be delivered to the students. Later, modification efforts with regard to the geography curriculum were conducted in 1970 (Khatijah, 1983). In 1989, the Integrated Curriculum for Secondary School (ICSS) was fully implemented and a special and detailed syllabus was introduced - the ICSS Geography Syllabus 1988. Later, a review process was carried out to form the ICSS 2000 Geography Syllabus which was adopted until 2016. At present, a new curriculum has been introduced once again - the StandardBased Curriculum for Secondary School (SBCSS) which replaced ICSS.

SBCSS has begun to be gradually implemented, starting with Form 1 in 2017, to meet the new policy requirements under the Malaysia Education Blueprint (MEB) 2013-2025, so that the quality of the curriculum is on par with international standards. According to Mohamad Fadzil and Abdul Jaleel (2013), the transformation of secondary education via MEB 2013-2025 shows that the government is aware and concerned about the development of existing education systems. This standard-based curriculum has been manifested in SBCSS through the formulation of the SDCA which contains several standards: specifically, content standards, learning standards, and performance standards for all subjects (Curriculum Development Division, 2015). At the lower secondary level, the focus of the SDCA of Geography is the proficiency of knowledge about spatial and environmental forms, and characteristics which should produce students with positive attitudes towards the environment. In order to achieve the focus of SDCA of Geography SBCSS, students need to master five aspects which include geography, physical geography, human geography, regional geography, and environmental issues and management.

\section{Changes in the Geography Courses Offered at UPSI}

Considering that the current geography curriculum for Forms 1, 2, and 3 has been renewed in terms of content, pedagogy, and assessment, a review of the curriculum for the B.Ed. in Geography is needed to produce geography teachers who are knowledgeable and meet the needs of the latest 
curriculum. The geography courses offered at UPSI are divided into three main themes: physical geography, human geography, and geographic skills. Physical geography consists of six courses: HGF3013 Introduction to Physical Geography, HGF3023 Natural Resources and Environmental Studies, HGF3033 Principles of Geomorphology, HGF3043 Climatology, HGF3053 Biogeography, and HGF3063 Studies of Tropical Hydrology. Human Geography comprises six courses: HGM3013 Introduction to Human Geography, HGM3023 Geography of Economy and Development, HGM3033 Population Geography, HGM3043 Urban and Metropolitan Geography, HGM3053 Regional Geography of Monsoon Asia, and HGM3063 Geography of Malaysia. Geographical Skills includes five courses, which include HGR3013 Techniques and Quantitative Methods in Geography, HGR3023 Research Methodology in Geography, HGG3013 Geographical Information Systems, HGG3023 Application of Geographical Information Systems and Spatial Analysis, and one university-required course which is a research project or final year project. These courses have to be completed within eight semesters and carry a total of 54 credit hours, including 80 credit hours of university courses and professional education. A study conducted by Mohd Mustamam et al. (2010) on the suitability of UPSI academic programmes with regard to the fields taught, found that $100 \%$ of geography graduates stated that the content learned met the teaching needs in schools.

In addition, the course is also offered to students from other programmes as a minor course of 24 credit hours. Among the courses offered in this way are HGF3013 Introduction to Physical Geography, HGM3013 Introduction to Human Geography, HGR3013 Techniques and Quantitative Methods in Geography, HGF3023 Natural Resources and Environmental Studies, HGM3033 Population Geography, HGF3043 Climatology, HGM3043 Urban and Metropolitan Geography, and HGM3063 Geography of Malaysia. A study conducted by Mohmadisa (2013) about the tendency of students from other programmes to choose geography as a minor programme at UPSI showed that the students had expressed positive attitudes and evaluated highly the courses offered by the Department of Geography. Respondents thought that the field of geography was an important field of study and that it is still needed in today's national education curriculum. Therefore this article will discuss on a comparison between the Bachelor of Education (B.Ed.) Geography curriculum and the Standard Document for Curriculum and Assessment (SDCA) of secondary school geography to find out whether there is are suitability and alignment in UPSI geography education curriculum and curriculum at school by Malaysia Ministry of Education.

\section{Methodology}

This study was conducted at Sultan Idris Education University (UPSI) in Tanjong Malim, Perak, Malaysia. The context of this study was to examine the content of the curriculum document of all the courses of the B.Ed. in Geography programme offered by the Department of Geography and Environment under the FHS. This study comprises a document analysis using a qualitative approach. This study only used secondary data collected from available sources (Fauzi, Jamal, \& Mohd Saifoul, 2014). Using this documentation method, two primary secondary data sources were gathered: specifically, the instructional plan (IP) of the courses included in the UPSI B.Ed. in Geography and the SDCA of Geography SBCSS of Forms 1, 2, and 3. This study only included 16 IP courses obtained from the Department of Geography and Environment, FHS, UPSI; the research project/final year project course was not included because the course is a university-required 
course. The SDCA of Geography SBCSS of Forms 1, 2, and 3 were obtained from the Curriculum Development Division, MOE.

The analysis technique applied in this study was document analysis which was used to compare the curriculum of the UPSI B.Ed. in Geography with that of the SDCA of Geography SBCSS in schools. This analysis is a scientific tool that involves specific procedures aimed at providing new insights, enhancing researchers' understanding regarding certain phenomena, or explaining practical action (Ford, 2004). Document analysis is a systematic procedure for reviewing or evaluating printed documents or electronic documents, such as computer-based and Internet materials (Bowen, 2009). This analysis was carried out using ATLAS.ti Version 8 software. ATLAS.ti is an effective software program for analysing qualitative data, especially for most text, visual, and audio data (Smit, 2002). In addition, ATLAS.ti can also assist in organising data, providing codes, and analysing research data efficiently and structurally (Afriansyah, 2016). The themes formed in the document analysis comprised physical geography, human geography, and geographic skills.

\section{Study Findings and Discussion}

\section{Curriculum Structure of UPSI B.Ed. in Geography and SDCA of Geography SBCSS}

The results of the document analysis show that 14 out of 16 B.Ed. in Geography courses were in line with Forms 1 to 3 SDCA of Geography SBCSS, which is shown in the relationship matrix displayed in Figure 1. As emphasised by Mohd Mustamam et al. (2010), programmes and syllabi offered must meet the current needs in order to be compatible with the national goals of producing many quality scholars. Mohd Zailani and Mohamad Khairi (2018) also mention that a high level of suitability of curriculum content could have a positive impact on future teachers in their preparation for becoming excellent new teachers and their willingness to take responsibility as an agent of national education transformation.

Figure 1. Relationship matrix between the courses of the UPSI B.Ed. in Geography and SDCA of Geography SBCSS of Forms 1 to 3 
INTERNATIONAL JOURNAL OF ACADEMIC RESEARCH IN PROGRESSIVE EDUCATION AND DEVELOPMENT

Vol. 8, No. 2, 2019, E-ISSN: $2226-6348$ @ 2019 HRMARS

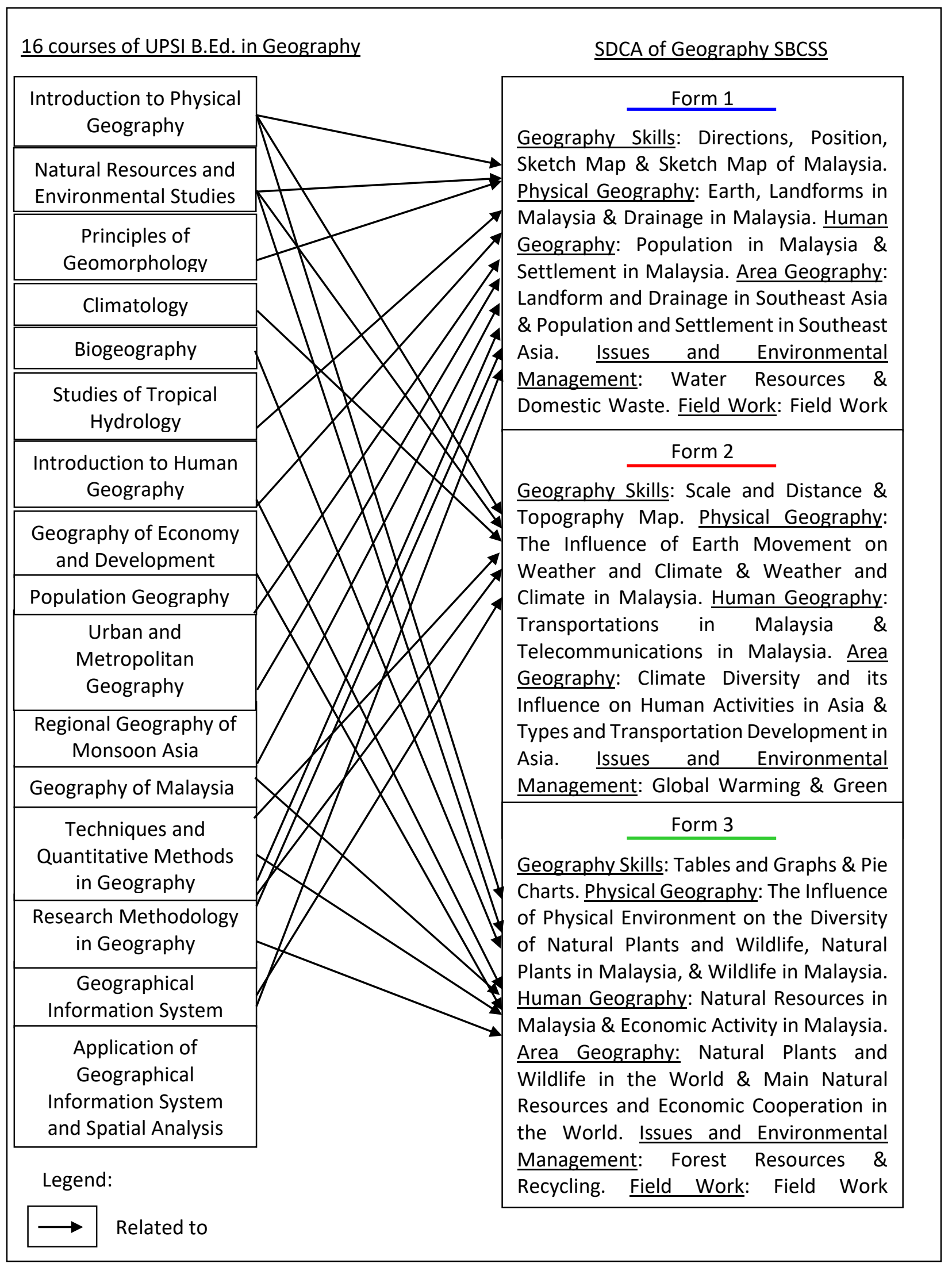


INTERNATIONAL JOURNAL OF ACADEMIC RESEARCH IN PROGRESSIVE EDUCATION AND DEVELOPMENT

Vol. 8, No. 2, 2019, E-ISSN: 2226-6348 @ 2019 HRMARS

Using ATLAS.ti, a document analysis was conducted through the processes of coding, categorising, and visual models in the form of networks. Thus, each course was divided into its respective code. The results of the document analysis found that the courses in the field of physical geography, specifically Introduction to Physical Geography, covered several topics represented in the SDCA of Forms 1 to 3, which included Earth and Water Resources (Form 1 SDCA), The Influence of Earth Movement on Weather and Climate and Global Warming (Form 2 SDCA), and The Influence of Physical Environment on the Diversity of Natural Plants and Wildlife (Form 3 SDCA; see Figure 2). As for the Natural Resources and the Environmental Studies course, several topics were comparable to the SDCA of Forms 1, 2, and 3, including Water Resources and Domestic Waste (Form 1 SDCA), Global Warming (Form 2 SDCA), and Forest Resources (Form 3 SDCA; see Figure 3). The Principles Geomorphology course only matched one topic of the Form 1 SDCA, which was the topic of Earth (Figure 4).

The results of the document analysis also found that the Climatology course was only comparable to Form 2 SDCA topics of The Influence of Earth Movement on Weather and Climate, Weather and Climate in Malaysia, Climate Diversity and its Influence on Human Activities in Asia, and Global Warming (Figure 5). In addition, the Biogeography course matched two topics of the Form 3 SDCA which were The Influence of Physical Environment on the Diversity of Natural Plants, and Wildlife and Natural Plants and Wildlife in The World (Figure 6). The course entitled Studies of Tropical Hydrology was only comparable to the topic Drainage in Malaysia and Water Resources (Form 1 SDCA; see Figure 7).

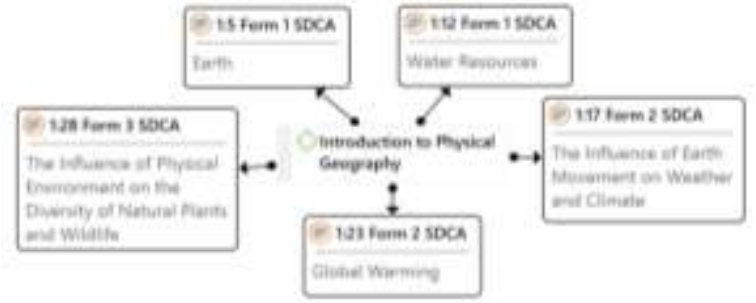

Figure 2. Codes for Introduction to Physical Geography course

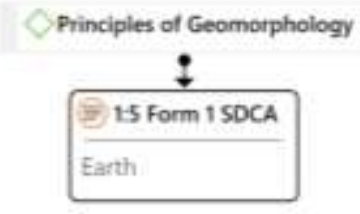

Figure 4. Code for Principles of Geomorphology course

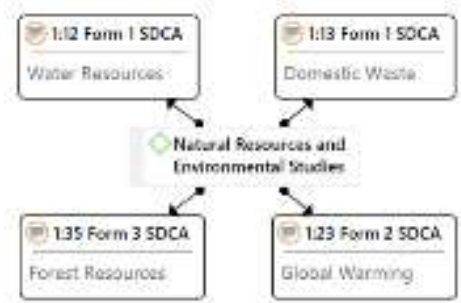

Figure 3. Codes for Natural Resources and Environmental Studies course

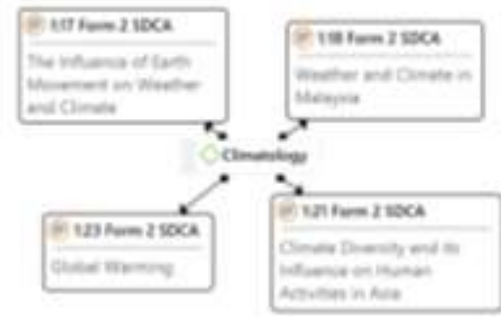

Figure 5. Codes for Climatology course 
INTERNATIONAL JOURNAL OF ACADEMIC RESEARCH IN PROGRESSIVE EDUCATION AND DEVELOPMENT

Vol. 8, No. 2, 2019, E-ISSN: 2226-6348 C 2019 HRMARS

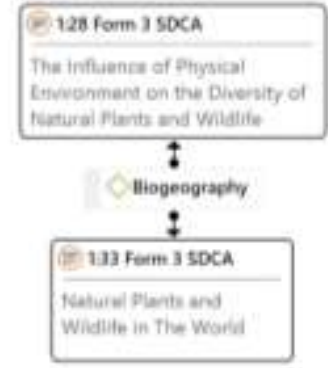

Figure 6. Codes for Biogeography course

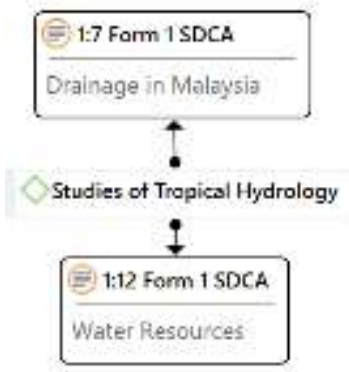

Figure 7. Codes for Studies of Tropical Hydrology course

The courses in Human Geography - Introduction to Human Geography - conformed to two topics in Form 1 SDCA, namely Population in Malaysia and Settlement in Malaysia, and one topic of Form 3 SDCA, which was Economic Activity in Malaysia (Figure 8). The Geography of Economy and Development course corresponded with only two topics in Form 3 SDCA: Economic Activity in Malaysia and Main Natural Resources and Economic Cooperation in the World (Figure 9). Similarly, the Population Geography course was only compatible with two Form 1 SDCA topics, namely Population in Malaysia and Population and Settlement in Southeast Asia (Figure 10). The Urban Geography and Metropolitan course only conformed to one Form 1 SDCA topic, which was Settlement in Malaysia (Figure 11). As for the Regional Geography of Monsoon Asia course, it was only similar to two Form 1 SDCA topics: namely, Landform and Drainage in Southeast Asia, and Population and Settlement in Southeast Asia (Figure 12). In addition, the document analysis found that the Geography of Malaysia course matched several Form 1 to 3 SDCA topics: specifically, Landforms in Malaysia and Population in Malaysia (Form 1 SDCA), Weather and Climate in Malaysia and Transportations in Malaysia (Form 2 SDCA), and Natural Resources in Malaysia, Economic Activity in Malaysia, and Main Natural Resources and Economic Cooperation in the World (Form 3 SDCA; see Figure 13).

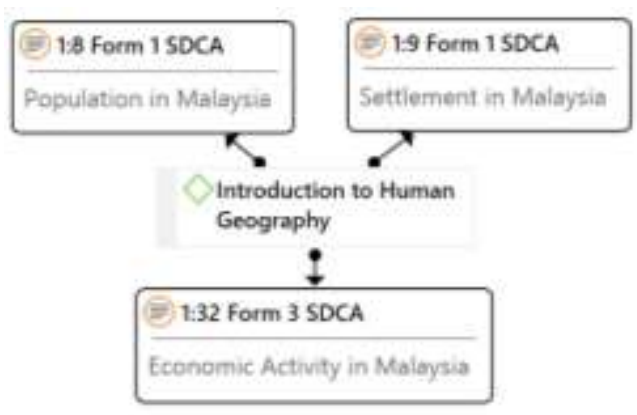

Figure 8. Codes for Introduction to Human Geography course

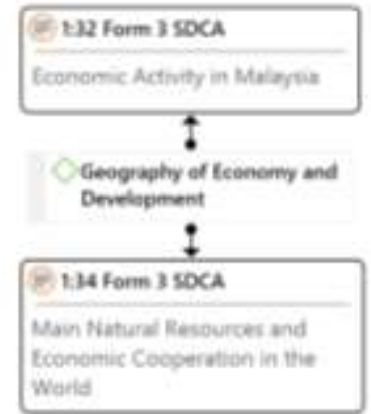

Figure 9. Codes for Geography of Economy and Development course 
INTERNATIONAL JOURNAL OF ACADEMIC RESEARCH IN PROGRESSIVE EDUCATION AND DEVELOPMENT

Vol. 8, No. 2, 2019, E-ISSN: 2226-6348 @ 2019 HRMARS

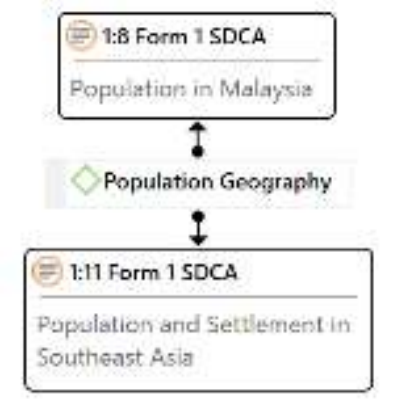

Figure 10. Codes for Population Geography course

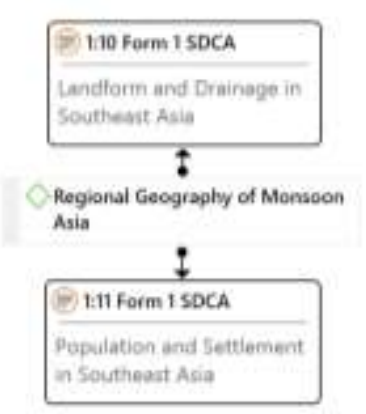

Figure 12. Codes for Regional Geography of Monsoon Asia course

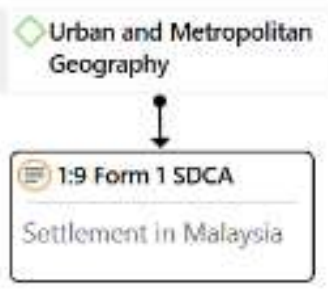

Figure 11. Codes for Urban and Metropolitan Geography course

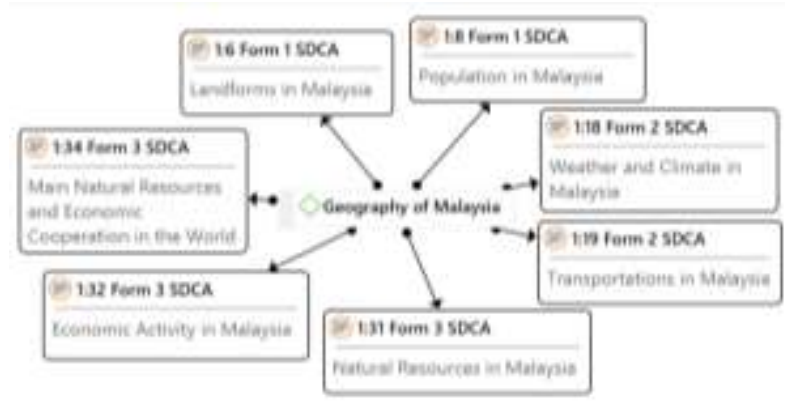

Figure 13. Codes for Geography of Malaysia course

In addition, the geographical skills course, Techniques and Quantitative Methods in Geography, matched two Form 1 SDCA topics - namely, Directions and Sketch Map; two Form 2 SDCA topics - namely Scale and Distance, and Topography Map; and two Form 3 SDCA topics namely Tables and Graphs, and Pie Charts (Figure 14). The Research Methodology in Geography course was comparable to the field work guide in Forms 1 to 3 SDCA (Figure 15).

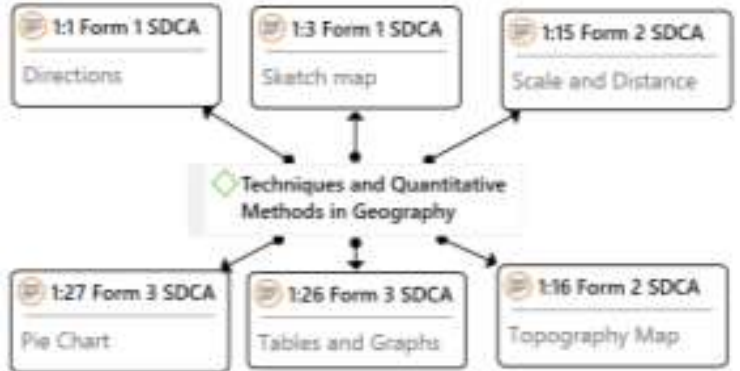

Figure 14. Codes for Techniques and Quantitative Methods in Geography course

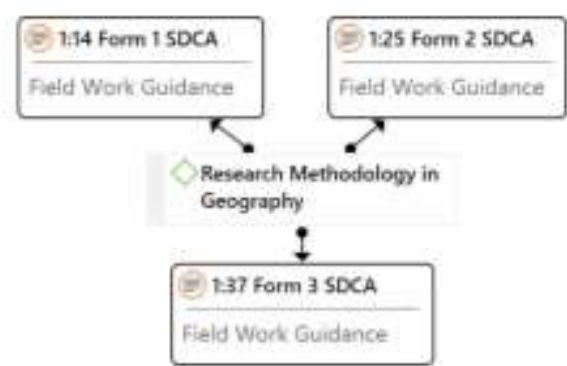

Figure 15. Codes for Research Methodology in Geography course

The study also found that two B.Ed. in Geography courses were not related to Forms 1 to 3 SDCA Geography SBCSS; these were Geographical Information Systems (GIS) and Application of Geographical Information System and Spatial Analysis, because GIS is not in the school's geography education curriculum. GIS is an information system used to store, display, analyse, and manipulate 
spatial-related data (Soon Singh, 2013). According to Acquah, Asamoah, and Konadu (2017), GIS is a software or tool that is capable of integrating both spatial data and attribute data represented. The MOE in Malaysia does not integrate GIS into geography education due a challenge with regard to a lack of skills among teachers and ICT facilities at schools (Soon Singh, 2013; Habibah \& Muniandy, 2011; Nordin, 2006). Deficiencies in terms of skills, human resources, and ICT facilities at schools will result in students not acquiring good GIS skills. In contrast, Kocalar and Demirkaya (2017) explain that well-equipped geography laboratories, qualified teachers, the use of teaching materials, and the active participation of students will enhance teachers' competence towards teaching and provide students with opportunities for more effective education in geography.

\section{Proposal to Improve B.Ed. in Geography Courses}

The results of the document analysis found that eight topics of SDCA of Geography SBCSS had no relationship with the IP of B.Ed. in Geography; this included two Form 1 topics (Position and Sketch Map of Malaysia), three Form 2 topics (Telecommunications in Malaysia, Types of and Transportation Development in Asia, and Green Technology), and three Form 3 topics (Natural Plants in Malaysia, Wildlife in Malaysia, and Recycling; see Figure 16). To overcome this problem, the faculty needs to play an important role in the improvement of the existing curriculum of the B.Ed. in Geography in order to conform to the current curriculum. This will indirectly upgrade the standard and improve the quality of the education system at the Faculty of Education (Hanifah et al., 2016). This will also help to produce quality educators who are equipped with $21^{\text {st }}$ century skills.

The results of the document analysis indicate that the topics of Position and Sketch Map of Malaysia should be emphasised in the Techniques and Quantitative Methods in Geography course because this topic is part of the geographic skills needed to be mastered by future teachers. In addition, the topic of Telecommunications in Malaysia should be emphasised in the Geography of Economy and Development course, while the topic of Types of and Transportation Development in Asia should be improved in the Regional Geography of Monsoon Asia course by focusing on transportation elements in Asia. Apart from that, the topic of Green Technology and Recycling should be highlighted in the Natural Resources and the Environmental Studies course. This is because green technology and recycling are environmental management methods rather than legislative measures. In addition, the topics of Natural Plants in Malaysia and Wildlife in Malaysia need to be improved upon in the two geography courses - namely, Biogeography and Geography of Malaysia - with regard to aspects of natural plants and wildlife which focus on Malaysia only. Therefore, a review of the existing curriculum which examines students' academic needs and improvements for future curricula is essential to achieve an effective curriculum (Zainudin et al., 2015). A study by Robiah (1998) also emphasises that assessment of university programmes should be conducted to ensure that educational services meet their goals and to serve as a medium to determine the overall effectiveness of the programmes. 
INTERNATIONAL JOURNAL OF ACADEMIC RESEARCH IN PROGRESSIVE EDUCATION AND DEVELOPMENT

Vol. 8, No. 2, 2019, E-ISSN: 2226-6348 @ 2019 HRMARS

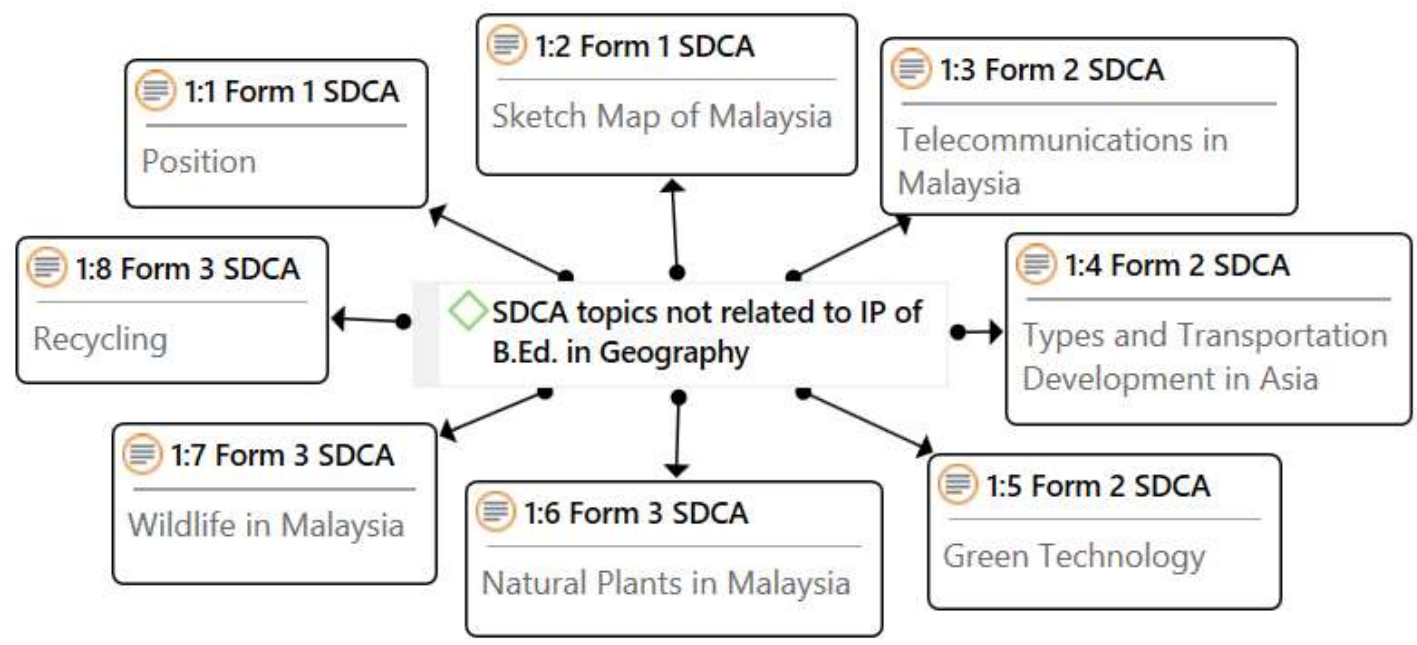

Figure 16. Codes of SDCA topics not related to IP of B.Ed. in Geography

In addition to the improvements to the IP of B.Ed. in Geography, several relevant new courses are also suggested so that teachers will have more knowledge which is in line with the latest education developments. Among the suggested courses are Transportation Geography, Industrial Geography, and Tourism Geography. According to Rodrigue, Comtois, and Slack (2016), Transportation Geography is a geography sub-discipline related to the movement of goods, persons, and information, with the purpose of linking spaces and attributes which include destinations and purposes of movement. This course should be established in the B.Ed. in Geography to reflect the two topics related to transport geography in Form 2 SDCA of Geography SBCSS - namely, Transportations in Malaysia and Types of and Transportation Development in Asia. This course should emphasise the aspects of historical development, types of transportation, and the importance and impact of transportation systems and their scope, not only in Malaysia but also in Asia and developed countries.

Industrial Geography refers to an economic geography sub-discipline with regard to the arrangement of manufacturing and secondary activity spaces, and has traditionally been defined as a study of spaces, places, and circulation of industrial geography (He \& Zhu, 2017). In this course, emphasis should be given to the distribution pattern and determination of industrial location, and the factors that influence this in social, economic, political, institutional, and technological contexts. This course is important in order to fulfil the Form 3 SDCA of Geography SBCSS topic of Economic Activity in Malaysia. In addition, a Tourism Geography should also be offered to future teachers of B.Ed. in Geography so that future teachers will not only learn about major economic activities such as industry, business, and agriculture, but also know more about tourism activities that are part of human economic activities. According to Salomia (2014), this course studies the relationship between places, landscapes, and humans, and reflects travel and tourism as economic, social, and cultural activities. It is fitting that these new courses be offered in the B.Ed. in Geography at UPSI. 
INTERNATIONAL JOURNAL OF ACADEMIC RESEARCH IN PROGRESSIVE EDUCATION AND

DEVELOPMENT

Vol. 8, No. 2, 2019, E-ISSN: 2226-6348 @ 2019 HRMARS

\section{Conclusion}

Overall, the results of the analysis show that 14 out of 16 courses in the B.Ed. in Geography were comparable to the SDCA of Geography SBCSS for Forms 1 to 3 that stated before. There were eight subjects in the SDCA of Geography SBCSS that were not related to the instructional plan of the B.Ed. in Geography: two from Form 1 topics that is Position and Sketch Map of Malaysia while three Form 2 topics which are Telecommunications in Malaysia, Types and Transportation Development in Asia, and Green Technology and three from Form 3 topics which are Natural Plants in Malaysia, Wildlife in Malaysia, and Recycling. The findings of this study should enhance the education system at university level to release quality future teachers who possess the latest knowledge and $21^{\text {st }}$ century skills.

Moreover, curriculum reviews are always needed to provide an education that is focused on human resource development to meet the country's social, economic, and political development needs. Therefore, this article suggest the updating of the B.Ed. in Geography programme to make it more relevant and complement the SDCA of Geography SBCSS of Forms 1 to 3 . This review advocates providing future geography teachers with the latest knowledge in line with the new school curriculum. In addition, these suggestion would also improve the quality of the education system at the faculty level by proposing improvements for existing courses and offering new relevant courses. Therefore, this article not only contributes to the updating of the existing UPSI B.Ed. in Geography curriculum, but also promotes the production of knowledgeable teachers who can use higher-order thinking skills during the teaching and learning process, which is in line with Malaysia's aspirations of becoming a developed nation.

\section{Acknowledgement}

Thank you to the Universiti Pendidikan Sultan Idris (UPSI) via the Research Management and Innovation Centre (RMIC) for providing the 2018 University Research Grant (Education) fund (Research Code: 2018-0039-107-01) used to carry out the research presented in this article.

\section{References}

Acquah, C. P., Asamoah, N. J., \& Konadu, D. D. (2017). Introduction of Geographical Information Systems (GIS) in Technical University Education in Ghana: Challenges and the way forward. Review of International Geographical Education Online (RIGEO), 7(2), 207-220.

Afriansyah, E. A. (2016). Penggunaan Software ATLAS. ti sebagai Alat Bantu Proses Analisis Data Kualitatif. Mosharafa: Jurnal Pendidikan Matematika, 5(2), 53-63. (In Malay)

Bahagian Pembangunan Kurikulum. (2015). Dokumen standard kurikulum dan pentaksiran Geografi Tingkatan 3 KSSM. Putrajaya: Bahagian Pembangunan Kurikulum. (In Malay)

Bowen, G. A. (2009). Document analysis as a qualitative research method. Qualitative Research Journal, 9(2), 27-40.

Connelly, F. M., \& Lantz, O. C. (1991). Definations of curriculum: An introduction. Dalam Lewy, A. (Ed.), The International Encyclopaedia of Curriculum (pp. 15-18). New York: Pergamon Press.

Djuwairiah, A. (2014). Understanding the 2013 curriculum of English teaching through the teachers and policymakers perspective. International Journal of Enhanced Research in Educational Development, 2(4), 6-15. 
INTERNATIONAL JOURNAL OF ACADEMIC RESEARCH IN PROGRESSIVE EDUCATION AND

DEVELOPMENT

Vol. 8, No. 2, 2019, E-ISSN: $2226-6348$ @ 2019 HRMARS

Egan, K. (2003). What is curriculum? Journal of the Canadian Association for Curriculum Studies, 1(1), 9-16.

Esteves, M. H. (2012). Geography education and citizenship education in Portugal: A challenge for the 21st century. SAGE Open, 2(4), 1-10.

Fauzi, H., Jamal, A., \& Mohd Saifoul, Z. N. (2014). Kaedah penyelidikan \& analisis data SPSS. Sintok, Kedah: Penerbit Universiti Utara Malaysia. (In Malay)

Ford, J. M. (2004). Content analysis: An introduction to its methodology. Personnel Psychology, 57(4), 1110-1113.

Habibah, L., \& Muniandy, V. (2011). GIS in the Malaysian geography education: Challenges and potentials. Geografia-Malaysian Journal of Society and Space, 7(1), 42-52.

Hanifah, M., Zainudin, O., Yazid, S., Mohmadisa, H., Adnan, J., \& Norazlan, H. Y. (2016). Keberkesanan kurikulum pendidikan sains sosial di Malaysia: Kajian perspektif guru siswazah dan pengetua sekolah di UPSI. Geografia - Malaysian Journal of Society and Space, 12(1), 3748. (In Malay)

He, C. F., \& Zhu, S. J. (2017). Industrial geography. In Richardson, D., Castree, N., Goodchild, M.M., Kobayashi, A., Liu, W.D., \& Marston, R. A. (Eds.), The International Encyclopedia of Geography. John Wiley \& Sons, Ltd.

Jamil, A., \& Norlia, G. (2008). Pentadbiran dan pengurusan sistem pendidikan Malaysia ke arah pendidikan berkualiti. Panitia Diklat Manajemen Guru Internasional 2008. (In Malay)

Kaya, N. (2018). Main challenges in front of the teachers to teach geography more effectively: A phenomenological research. Review of International Geographical Education Online (RIGEO), $8(2), 371-393$.

Khatijah, K. (1983). Kurikulum geografi di sekolah-sekolah menengah. Pendidik dan Pendidikan, 5(1), 54-60. (In Malay)

Kocalar, A. O., \& Demirkaya, H. (2017). Geography teachers' views on effective geography teaching. Review of International Geographical Education Online (RIGEO), 7(3), 332-346.

Merfat Ayesh, A. (2016). Curriculum development: Teacher involvement in curriculum development. Journal of Education and Practice, 7(9), 106-107.

Mohamad Fadzil, C. A., \& Abdul Jaleel, A. H. (2013). Menilai keberkesanan pelaksanaan program Diploma Perguruan Lepasan ljazah Pendidikan Pendidikan Sejarah sekolah rendah di Institut Pendidikan Guru Kampus Puala Pinang. Dalam Seminar Pendidikan Sejarah dan Geografi (pp. 214-225). Universiti Malaysia Sabah. (In Malay)

Mohamad Suhaily Yusri, C. N. (2002). Pengantar persekitaran fizikal. Tanjong Malim: Penerbit Universiti Pendidikan Sultan Idris. (In Malay)

Mohd Mustamam, A. K., Zakaria, K., Mohamad, I., Mohd Ramli, B. K., Amir Hasan, D., Ahmad, H., Che Mohd Zuklifli, C.O., Mohamad Suhaily Yusri, C.N., Saberi, O., Adnan, M.N., Haji Iberahim, H., Abdul Kadir, A., Mohd Nazri, M.S, \& Mohammad Sidik, A. (2010). Kajian penyesuaian program pengajian UPSI dengan bidang pekerjaan (Graduan 1999-2009). Laporan Penyelidikan Geran Penyelidikan UPSI yang tidak diterbitkan. Tanjong Malim. (In Malay)

Mohd Zailani, I., \& Mohamad Khairi, O. (2018). Penilaian kesesuaian kurikulum Program Ijazah Sarjana Muda Perguruan (PISMP) pendidikan Islam di Institut Pendidikan Guru Malaysia. Internatinal Journal of Education, Psychology and Counseling, 3(8), 91-106. (In Malay)

Mohmadisa, H. (2013). Kecenderungan pelajar Universiti Pendidikan Sultan Idris (UPSI) memilih 
INTERNATIONAL JOURNAL OF ACADEMIC RESEARCH IN PROGRESSIVE EDUCATION AND DEVELOPMENT

Vol. 8, No. 2, 2019, E-ISSN: 2226-6348 @ 2019 HRMARS

minor geografi. Dalam Habibah, H.L., Wan Rozali, W.H., Sibly, M., \& Misni, S. (Eds.), Isu-isu semasa dalam pendidikan geografi di Malaysia (pp. 29-46). Pulau Pinang: Pusat Pengajian Jarak Jauh, USM. (In Malay)

Nor Fauzian, K., \& Fauziah Hanim, A. J. (2015). Kurikulum pendidikan awal kanak-kanak dan modul pendidikan akhlak: Isu dan cabaran masa kini. Dalam Seminar Penyelidikan Kebangsaan. UPSI, Tanjong Malim. (In Malay)

Nordin, S. (2006). Teaching GIS in Sabah: An early survey towards GIS in schools in environmental geography and education. Tanjong Malim: Penerbit Universiti Pendidikan Sultan Idris.

Robiah, S. (1998). Pemikiran dalam pendidikan. Shah Alam: Penerbit Fajar Bakti Sdn. Bhd. (In Malay)

Rodrigue, J. P., Comtois, C., \& Slack, B. (2016). The geography of transport systems. (4th ed.). New York: Routledge.

Salomia, S. F. (2014). What is tourism geography? Retrieved August 11, 2018, from https://www.geolounge.com/tourism-geography/

Smit, B. (2002). ATLAS.ti for qualitative data analysis. Perspectives in Education, 20(3), 65-75.

Soon Singh, B. S. (2013). Integrating geography information system in teaching geography in Malaysian secondary smart schools. Education Journal, 2(4), 149-154.

Voon, P. K. (1990). Geography education in Malaysia. Malaysian Journal of Tropical Geography, 21(2), 92-111.

Zainudin, O., Mohamad Suhaily Yusri, C. N., Mohd Faris, D., Mohmadisa, H., Norazlan, H. Y., Hanifah, M., Yazid, S., Adnan, J., \& Ahmad Yunus, K. (2015). Penilaian pelaksanaan program ljazah Sarjana Muda Pendidikan, Fakulti Sains Kemanusiaan, Universiti Pendidikan Sultan Idris. Laporan Penyelidikan Geran Penyelidikan Top Down (GPU) UPSI yang tidak diterbitkan.Tanjong Malim. (In Malay)

Corresponding Author

Mohmadisa Hashim

Email:mohmadisa@fsk.upsi.edu.my 